\title{
The significance of neonatal thymectomy for shaping the immune system in children with congenital heart defects
}

\author{
Małgorzata Stosio ${ }^{1}$, Jakub Ruszkowski ${ }^{1}$, Anna Mikosik-Roczyńska ${ }^{1}$, Ireneusz Haponiuk ${ }^{2,3}$, Jacek M. Witkowski ${ }^{1}$ \\ ${ }^{1}$ Department of Physiopathology, Medical University of Gdańsk, Poland \\ ${ }^{2}$ Department of Pediatric Cardiac Surgery, Pomeranian Traumatology Center, Gdańsk, Poland \\ ${ }^{3}$ Department of Physiotherapy, Faculty of Rehabilitation and Kinesiology, Gdańsk University of Physical Education, Poland
}

Kardiochirurgia i Torakochirurgia Polska 2017; 14 (4): 258-262

\begin{abstract}
The thymus plays an important role in the development of the immune cell pool; it serves as the primary location for T-lymphocyte maturation. Early cardiac surgical interventions for congenital heart defects are necessarily associated with thymectomy, i.e. the partial or complete removal of the thymus. A newborn infant already has a functioning thymus and developed cells of the immune system. However, thymectomy eliminates the primary location where T cells differentiate and mature. This study summarizes the current knowledge of the cellular disturbances and potential clinical consequences associated with performing thymectomy in children treated surgically for congenital heart defects.
\end{abstract}

Key words: thymus, congenital heart defect, thymectomy, naive T lymphocyte.

\section{Introduction}

Congenital anomalies of the cardiovascular system constitute the most frequent type of genetic disturbances diagnosed in neonates. Current epidemiological data indicate that almost 1 in 100 children is born with a heart defect. While some cardiovascular disorders in newborns may be asymptomatic or mild, other complex, critical defects of the heart or vessels require urgent surgical treatment. Performing early surgical correction in such cases is necessary to save the lives of young infants showing symptoms of cyanosis and heart failure [1].

Over the past 30 years, neonatal open heart surgery has become a routine method of treating critical congenital heart defects; it is often supplemented with the increasingly popular percutaneous interventions. Early surgical interventions for congenital heart defects are necessarily associated with thymectomy, i.e., the partial or complete removal of the thymus. In neonates this procedure is performed routinely for technical reasons as the size and location of the thymus impede access to the heart during

\section{Streszczenie}

Grasica odgrywa istotną rolę w kształtowaniu się puli komórek układu odpornościowego, stanowi główne miejsce dojrzewania limfocytów T. Wczesne interwencje kardiochirurgiczne we wrodzonych wadach serca nieodzownie łączą się z tymektomią - zabiegiem całkowitego lub częściowego usunięcia grasicy. Noworodki mają już funkcjonalną grasicę oraz rozwinięte komórki układu odpornościowego, jednak zabieg tymektomii uważa się za przyczynę eliminacji głównego ośrodka różnicowania i dojrzewania limfocytów T. Niniejsza praca jest podsumowaniem obecnej wiedzy na temat zaburzeń na poziomie komórkowym oraz potencjalnych klinicznych konsekwencji tymektomii u dzieci leczonych operacyjnie z powodu wrodzonych wad serca.

Słowa kluczowe: grasica, wrodzona wada serca, tymektomia, dziewiczy limfocyt T.

surgery. Thymus removal also eliminates the risk of compression on the heart and great vessels by the swollen gland affected by intracapsular infiltration during the early postoperative period [2].

Regardless of the method used to perform cardiac surgery in neonates, one should keep in mind that the thymus plays an important role in the formation of the immune cell pool and is the primary location of T-cell maturation. As early as during the $8^{\text {th }}-9^{\text {th }}$ week of pregnancy, the first T-cell precursors find their way to the thymus from bone marrow; the first naive T cells leave the thymus during the $14^{\text {th }}-15^{\text {th }}$ week of fetal life [3]. Contrary to previous beliefs, the neonatal immune system is not immature, but its response to antigens differs from that observed in adults. In humans, a neonate is born with an already functioning thymus and developed immune cells, even though human thymus achieves optimal effectiveness as late as during puberty [4].

In view of the lack of unequivocal evidence for the occurrence of immune disturbances in patients after neonatal

Address for correspondence: Małgorzata Stosio, Department of Physiopathology, Medical University of Gdańsk, 7 Dębinki St, 80-211 Gdańsk, Poland, phone: +48 5834915 10, fax: +48 58349 15 10, e-mail: mstosio@gumed.edu.pl

Received: 4.04.2017, accepted: 12.11.2017. 
thymectomy, there is currently a widespread conviction that the risk associated with removing the thymus is minimal in comparison to the undisputed technical benefits important for cardiac surgeons. Notwithstanding, the long-term consequences of thymectomy, routinely performed in neonatal cardiac surgery, are still little known despite numerous studies [1]. It also cannot be excluded that thymectomy impacts the formation of the immune system and may have clinical consequences for the patient when performed during the early period of immune system development. The procedure is believed to eliminate the main center for T-cell differentiation and maturation in adults $[5,6]$.

The aim of this study is to summarize the current knowledge of the cellular disturbances and potential clinical consequences associated with thymectomy performed in surgically treated neonates with congenital heart defects. Based on the current knowledge of the role of the thymus in the formation and maintenance of adequate immune function in humans (not only during early childhood), our goal is to draw attention to the potential benefits of modifying the operative technique in order to preserve this gland in whole or in part.

\section{T-cell maturation}

T lymphocytes are responsible for the body's specific, cellular immune response to foreign antigens. The thymus plays a key role in the production and maintenance of naive T cells in the periphery and ensures their diversity. This is why it is so important that the pool of cells undergoing proliferation and maturation in the thymus is as large as possible.

Thymocyte maturation in the thymus occurs in several stages, including primarily: $\beta$ selection, positive selection, and negative selection. The control of the proper rearrangement of genes encoding the T-cell receptors (TCRs) is known as $\beta$ selection. Thymocytes with abnormal $\beta$ chain structure undergo apoptosis, while the remaining thymocytes begin to rearrange the $\alpha$ chain genes and produce CD4 and CD8 surface proteins, resulting in the formation of double positive thymocytes (with phenotype $\mathrm{CD} 4^{+} \mathrm{CD} 8^{+}$). Positive selection occurs when a properly constructed TCR is stimulated by antigens presented by its own MHC molecules; thymocytes with abnormal receptor structure are not stimulated and die "from neglect". Additionally, the cell is skewed toward a $\mathrm{CD}^{+}$or $\mathrm{CD} 8^{+}$phenotype, depending on the reaction with the appropriate class of $\mathrm{MHC}$ molecules. In turn, negative selection entails the apoptosis of thymocytes whose response to autoantigens is too strong, which constitutes one of the mechanisms that protect the organism from the development of autoimmune diseases [7, 8].

The physiological role of the thymus in the formation of naive T cells with broad TCR repertoire (which enables a specific response to practically any antigen originating from a pathogen), the role of positive selection in the formation of lymphocyte population, and the role of negative selection in the prevention of autoimmune diseases warrant the consideration whether early thymectomy causes deficits in specific immune response and whether it increases the risk of autoimmune diseases. Such clinical sequelae are observed, for example, in individuals with congenital thymic aplasia or hypoplasia [9]. Moreover, the risk of abnormal lymphocyte function increases with age, which has also been correlated with reduced thymic function [10].

\section{The role of the thymus in the proper development of the naive $\mathrm{T}$-cell population}

The term naive $T$ cells denotes immunocompetent cells that have left the thymus, but are yet to come into contact with antigens recognized by their TCRs and to differentiate into effector cells and, later, memory cells [11].

After the first year of life, naive T-cell production in the thymus begins to decrease until it becomes scant in adults [10]. Interestingly, as humans mature, the total number of naive $T$ cells remains practically unchanged despite the gradual reduction in thymus function and the increasing pool of effector and memory cells, owing to the so-called peripheral homeostatic proliferation of T cells: human naive $T$ cells have the ability to proliferate outside the thymus without losing their functional properties [11].

The studies published so far indicate that naive $T$ cells can be classified into two subpopulations differing in the expression of the CD31 surface antigen (PECAM-1); their proportions change over the course of human life. And so, one of the characteristics of T cells that have already left the thymus is the presence of a CD31 surface molecule. With subsequent divisions, the CD31 marker is lost in the population of naive $T$ cells, which results in the creation of a population of naive CD31 cells $[12,13]$. As a natural consequence of the decreasing role of the thymus, the number of $\mathrm{CD}_{3} 1^{+}$lymphocytes in peripheral circulation decreases gradually with age. In turn, the drop in the number of CD31+ cells is drastic in patients undergoing thymectomy [14, 15]. The potential influence of the changes in the proportions of naive T cells for the development of the immune system throughout life has not yet been explained [4, 12].

With age, the percentage of $\mathrm{CD}^{-} 1^{-}$cells in the naive Tcell population rises, which may reduce the immune system's ability to respond to vaccines or numerous infections. Therefore, the loss of naive $\mathrm{CD} 31^{+}$cells may be detrimental to the immune system [16].

Studies conducted among 5-year-old children undergoing thymectomy (compared with healthy children of the same age) demonstrated that the performance of thymectomy during the first month of life caused a significant reduction in the population of T cells, and significant differences have been noted in the percentage of naive $T$ cells $\left(\mathrm{CD} 31^{+}\right)$in comparison to healthy individuals. A group was identified among the thymectomized patients that was characterized by a small number of cells showing signs of CD31 presence, which would indicate thymus dysfunction; no thymus regeneration was observed among these patients $[4,14,17,18]$. 
Removing the thymus (partially or completely) eliminates the niche in which the thymocytes differentiate and mature. It seems unavoidable that this results in functional disturbances. Consequently, children undergoing thymectomy are observed to lose the production of IL-8, which constitutes an effector marker for some of the naive, immature $\mathrm{CD}^{+}$cells in neonates and is responsible for early immune defense $[4,19]$. Concurrently, the production of interferon- $\gamma$ (IFN- $\gamma$ ) by naive T cells increases, indicating that a functional change occurs in these cells as they prematurely acquire properties of the adult immune system [17, 20].

A comparison of the expression of genes responsible for T-cell activation pathways in naive $C D 31^{+}$cells in healthy children and children undergoing thymectomy revealed differences in the expression of more than 200 genes. Additional focus was given to the subpopulations of $\mathrm{CD} 31^{+}$and CD $31^{-}$cells in both study groups, demonstrating that, in the thymectomy group (as opposed to healthy controls), gene expression was similar in both subpopulations; this indicates that, after thymectomy, T cells may acquire a phenotype similar to the CD31- cells even if they do not lose the CD31 molecule [4].

Another finding was that the proliferation of CD31 cells outside the thymus (increased by thymectomy due to the shortage of thymic $\mathrm{CD} 31^{+}$cells) may be supported by selfantigens, which leads to positive selection and expansion of potentially autoreactive cells, consequently facilitating the development of autoimmune diseases [11].

There is currently no evidence for the impact of thymectomy on the rate at which $T$ cells mature in the periphery. Moreover, according to Bains et al., thymectomy is associated with a compensatory peripheral increase in the proliferation of naive $T$ cells $[17,21]$. However, a study by Elder et al. indicates that the naive $T$ cells forming and differentiating outside the thymus are characterized by early exhaustion, associated with the lower initial diversity of these cells [10]. Other studies show that total (but not partial) thymectomy performed at the age of approximately 14 days results in disturbances in T-cell response for several years after the surgery [22].

Currently, the role of the thymus in the formation of T-cell phenotypes is considered to be much more significant than initially believed. Young adults after thymectomy show cell differentiation skewed towards effector $T$ cells as well reduced TCR repertoire, similar to those observed in elderly individuals [12]. Therefore, the population of T cells in patients in whom the thymus was removed during the first month of life shows certain signs of premature aging [14].

\section{The impact of thymectomy on the immune system}

Numerous studies on thymectomy patients indicate long-term disturbances in the production of T cells. Some researchers have demonstrated reductions in the total number of $\mathrm{CD}^{+}$and $\mathrm{CD}^{+}$cells $[3,14,23]$ and accumulations of oligoclonal memory cells as late as 22 years after thymectomy [14]. In turn, other results suggest that, despite the dropping number of $\mathrm{CD} 4^{+}$cells, the number of cytotoxic lymphocytes $\left(C D 8^{+}\right)$remains unchanged [24-26]. Mancebo's research team examined patients after thymectomy, revealing progressive lymphopenia, especially in the population of naive $\mathrm{CD}^{+}$cells [27]. Observations of changes in other immune cell populations yielded controversial results. The study by Mancebo et al. cited above found no changes in B cells or NK cells, while demonstrating a significant increase in the number of neutrophils [27], which would confirm the suggestions that the role of cells responsible for congenital response increases in the presence of a deficit in acquired response. This has not been confirmed by Brearley et al., who reported a statistically significant reduction in the population of neutrophils, an additional increase in the population of B cells, and increased production of IgA antibodies [25].

The mechanism leading to great repertoire diversity in TCRs consists in rearranging the genes for the components of these receptors. The rearrangement results in the formation of circular DNA molecules excised from the genome, known as T-cell receptor excision circles (TRECS). TRECS are not reproduced in subsequent divisions; therefore, the measurement of their relative number among the naive $T$ cells is used to evaluate the ability of the thymus to produce them. Long-term reductions in the number of TRECs were observed in thymectomy patients compared to healthy individuals [27-29]. Results obtained by Cao et al. showed that the number of naive, TREC-containing T cells may be associated with the size of the preserved thymus fragment. In the group of patients after partial thymectomy (<50\%), the number of TRECs increased after 3 months from the surgery, and preoperative levels were restored after a year; among the remaining patients (in whom more than half of the thymus was removed) the number of TRECS remained significantly lower than the preoperative values, and this effect persisted in the long term [30]. Thymectomy was also shown to be associated with a decrease in the TCR repertoire and the number of regulatory nTreg cells as well as an increase in the expression of cytokines such as IL-2, IFN- $\gamma$, and IL-4 [30].

The changes in the pool of immune system cells and the disturbances in cytokine expression indicate that thymectomy has a significant influence on the immune function of peripheral T cells, B cells, and cells responsible for congenital immune response $[28,30]$. Further clinical consequences of these changes are yet to be established.

Of particular interest is the fact that some patients show signs of thymic regrowth after 5-10 years from thymectomy, which indicates that the thymus may have previously unsuspected regenerative capability. For now it remains unknown whether this ability of the thymus to (at least partially) regenerate enables the complete restoration of the normal number of $T$ cells and normal proportions in their populations [4]. Studies on murine DiGeorge syndrome models that were transplanted with murine thymus fragments indicated normal thymopoiesis; T-cell proliferation increased from $10 \%$ to $100 \%$ [31]. Numerous studies 
on thymic regeneration clearly indicate its potential in the treatment of immune disorders [32, 33] (Tab. I).

It should be stressed, however, that the thymus does not regenerate in all children after thymectomy. This may be attributed to the age at which the organ is removed; better thymic regeneration was observed in children who underwent the procedure during the first month of life. Other factors may include the size, shape, or location of the preserved fragment of the thymus [4]. It should be noted that some studies definitely exclude thymic regeneration in humans [17, 28]. Therefore, it seems even more important that the thymus fragment preserved during cardiac surgery is as large as possible to increase the chance of tissue regeneration.

\section{Clinical consequences of thymectomy}

As early as 1987, Brearley et al. examined 18 children (aged up to 3 years old) after thymectomy. All subjects exhibited reduced response to antigens in comparison to healthy controls. Although the results proved not to be statistically significant, the authors' recommendation was to avoid routine thymectomy whenever possible [25]. Another suggestion for cases in which the organ could not be preserved was to perform a thymic transplant (reimplantation) after the successful cardiac procedure [22].

Recent studies have shown that thymectomy leads to the production of antibodies with decreased antigen affinity. The results of these studies indicate that the thymus indirectly controls the process of the maturation and selection of B cells producing high-affinity antibodies [28, 30].

The conclusions of clinical studies conducted to examine the influence of thymectomy on immune cells are not unequivocal. When analyzing the results, one should consider that neonates with heart defects are often treated with steroids or catecholamines. Some of these agents reduce the total number of $\mathrm{T}$ cells. Studies indicate that thymectomy leads to the gradual loss of recent thymic emigrant (RTE) phenotypes, lack of thymic hormones, increased selective homeostatic proliferation, and an altered cytokine environment [4].

Some studies show that patients undergoing thymectomy as neonates are more likely to suffer from age-related diseases, such as autoimmune diseases, cancer, atherosclerosis, or neurodegenerative diseases [12]. According to other studies, individuals without a thymus have a greater tendency to develop rashes, eczema, or contact allergies [28].

Different results were obtained by Mancebo et al.; their data indicate that children thymectomized as neonates are not more predisposed to immune system diseases. Although such children are not more likely to contract infections, the duration of their treatment and hospitalization due to typical infectious diseases (e.g., bronchitis) is significantly longer [22], as is the time required for their immune system to recover from infections [27, 30]. Detailed histopathological assessment and immunological diagnostics after thymus removal may lead to the early diagnosis of non-neoplastic hyperplastic diseases, such as histiocytosis [2] (Tab. II).
Tab. I. Changes in the immune systems of patients undergoing thymectomy

\begin{tabular}{lc}
$\begin{array}{l}\text { Complications affecting } \\
\text { the immune systems of patients } \\
\text { undergoing thymectomy }\end{array}$ & Author (reference) \\
$\begin{array}{l}\text { Reduction of the total number } \\
\text { of CD4+ and CD8 }{ }^{+} \text {T cells }\end{array}$ & $\begin{array}{c}\text { Holt et al. [3] } \\
\text { Sauce et al. [14] } \\
\text { Opiela et al. [23] }\end{array}$ \\
\hline $\begin{array}{l}\text { Reduction of CD4+ T cells, but } \\
\text { no reduction of CD8 }{ }^{+} \text {T cells }\end{array}$ & $\begin{array}{c}\text { Eysteinsdottir } \text { et al. [24] } \\
\text { Wells et al. [26] }\end{array}$ \\
\hline $\begin{array}{l}\text { Lymphopenia } \\
\text { No changes in B lymphocytes } \\
\text { or NK cells }\end{array}$ & Mancebo et al. [27] \\
\hline $\begin{array}{l}\text { Increased population of B cells, } \\
\text { and increased production of lgA } \\
\text { antibodies }\end{array}$ & Brearley et al. [25] \\
\hline $\begin{array}{l}\text { Increased number of neutrophils } \\
\text { Reduced neutrophil population }\end{array}$ & Eysteinsdottir et al. [24] \\
\hline $\begin{array}{l}\text { Reduced number of regulatory cells } \\
\text { Reduced TCR repertoire } \\
\text { Increased concentration of cytokines } \\
\text { (IL-2, IFN- } \gamma \text {, IL-4) }\end{array}$ & Wells et al. [26] \\
\hline
\end{tabular}

Tab. II. Results of studies on the clinical consequences of thymectomy

\begin{tabular}{lc} 
Clinical consequences of thymectomy & Author (reference) \\
$\begin{array}{l}\text { Increased risk of autoimmune diseases } \\
\text { and neurodegenerative diseases }\end{array}$ & Zlamy et al. [12] \\
\hline $\begin{array}{l}\text { Lesser response to some vaccines } \\
\text { (e.g., against tick-borne encephalitis) }\end{array}$ & Prelog et al. [17] \\
\hline $\begin{array}{l}\text { Longer hospitalizations with typical } \\
\text { infections }\end{array}$ & Kurobe et al. [22] \\
\hline $\begin{array}{l}\text { No differences in disease incidence } \\
\text { Longer recovery after infections }\end{array}$ & $\begin{array}{c}\text { Mancebo et al. [27] } \\
\text { Cao et al. [30] }\end{array}$ \\
\hline
\end{tabular}

\section{Conclusions}

The routine removal of the whole or part of the thymus, which accompanies the surgical treatment of congenital heart defects, has a significant impact on the formation of the immune cell pool and the maintenance of the phenotype and functionality of naive T cells later in the patient's life. The thymus's ability to regenerate warrants the modification of operative techniques to enable the preservation of this gland, or its larger fragment, during neonatal cardiac surgery. Despite numerous cellular changes in the immune system, thymectomized patients do not exhibit specific clinical symptoms that could be associated directly to thymectomy alone. Current studies indicate that complete or partial thymectomy results in accelerated aging of the immune system and reduces T-cell diversity, which may consequently lead to increased susceptibility to autoimmune or neurodegenerative disease [12]. Further studies (especially long-term) are required to establish the late consequences of thymectomy. 


\section{Disclosure}

Authors report no conflict of interest.

\section{References}

1. Kapersky E, Wierzba J, Limon J. Epidemiologia wrodzonych wad rozwojowych zarejestrowanych w województwie pomorskim w latach 2003-2005. Epidemiology of congenital malformations in the Pomerania Province in the years 2003 - 2005. Ann Acad Med Gedan 2008; 38: 25-35.

2. Jaworski R, Haponiuk I, Irga N, Chojnicki M, Steffek M. Makroskopowe zmiany $w$ grasicy $u$ dziecka leczonego kardiochirurgicznie - znaczenie oceny śródoperacyjnej w rozpoznaniu histiocytozy. Kardiochir Torakochir Pol 2011; 8: $475-477$.

3. Holt PG, Jones CA. The development of the immune system during pregnancy and early life. Allergy 2000; 55: 688-697.

4. van den Broek T, Delemarre EM, Janssen WJ, Nievelstein RA, Broen JC, Tesselaar K, Borghans JA, Nieuwenhuis EE, Prakken BJ, Mokry M, Jansen NJ, van Wijk F. Neonatal thymectomy reveals differentiation and plasticity within human naive T cells. J Clin Invest 2016; 126: 1126-1136.

5. Abo T. Extrathymic pathways of T-cell differentiation and immunomodulation. Int Immunopharmacol 2001; 1: 1261-1273.

6. Blais ME, Louis I, Corneau S, Gérard G, Terra R, Perreault C. Extrathymic T-lymphocyte development. Exp Hematol 2003; 31: 349-354.

7. Hedrick SM. Thymus lineage commitment: a single switch. Immunity 2008; 28: 297-299.

8. Singer A, Adoro S, Park J. Lineage fate and intense debate: myths, models and mechanisms of CD4-versus CD8-lineage choice. Nat Rev Immunol 2009; 8: 788-801.

9. Davies EG. Immunodeficiency in DiGeorge syndrome and options for treating cases with complete athymia. Front Immunol 2013; 4: 322.

10. Elder RW, George RP, McCabe NM, Rodriguez FH III, Book WM, Mahle WT, Kirk AD. Immunologic aging in adults with congenital heart disease: does infant sternotomy matter? Pediatr Cardiol 2015; 36: 1411-1416.

11. Kohler S, Thiel A. Life after the thymus: CD31+ and CD31 human naive CD4+ T-cell subsets. Blood 2009; 113: 769-774.

12. Zlamy M, Almanzar G, Parson W, Prelog M. Efforts of the human immune system to maintain the peripheral CD8+ T cell compartment after childhood thymectomy. Immun Ageing 2016; 13: 3.

13. Kimmig S, Przybylski GK, Schmidt CA, Laurisch K, Möwes B, Radbruch A, Thiel A. Two subsets of naive Thelper cells with distinct $T$ cell receptor excision circle content in human adult peripheral blood. J Exp Med 2002; 195: 789-794.

14. Sauce D, Larsen M, Fastenackels S, Duperrier A, Keller M, Grubeck-Loebenstein B, Ferrand C, Debré P, Sidi D, Appay V. Evidence of premature immune aging in patients thymectomized during early childhood. J Clin Invest 2009; 119: 3070-3078.

15. Kilpatrick RD, Rickabaugh T, Hultin LE, Hultin P, Hausner MA, Detels R, Phair J, Jamieson BD. Homeostasis of the naive CD4+ T cell compartment during aging. J Immunol 2008; 180: 1499-1507.

16. Naylor K, Li G, Vallejo AN, Lee WW, Koetz K, Bryl E, Witkowski J, Fulbright J, Weyand CM, Goronzy J. The influence of age on T cell generation and TCR diversity. J Immunol 2005; 174: 7446-7452.
17. Prelog $M$, Keller M, Geiger R, Brandstätter A, Würzner R, Schweigmann U, Zlamy M, Zimmerhackl LB, Grubeck-Loebenstein B. Thymectomy in early childhood: significant alterations of the CD4+CD45RA+CD62L+ T cell compartment in later life. Clin Immunol 2009; 130: 123-132.

18. Van Gent R, Schadenberg AWL, Otto SA, Nievelstein RA, Sieswerda GT, Haas F, Miedema F, Tesselaar K, Jansen NJ, Borghans JA. Long-term restoration of the human $\mathrm{T}$-cell compartment after thymectomy during infancy: a role for thymic regeneration? Blood 2011; 118: 627-634.

19. Gibbons D, Fleming P, Virasami A, Michel ML, Sebire NJ, Costeloe K, Carr R, Klein N, Hayday A. Interleukin-8 (CXCL8) production is a signatory T cell effector function of human newborn infants. Nat Med 2014; 20: 1206-1210.

20. Goronzy JJ, Fang F, Cavanagh MM, Qi Q, Weyand CM. Naïve T cell maintenance and function in human aging. J Immunol 2015; 194: 4073-4080.

21. Bains I, Yates AJ, Callard RE. Heterogeneity in thymic emigrants: implications for thymectomy and immunosenescence. PLoS One 2013; 8: 1-10.

22. Kurobe H, Tominaga T, Sugano M, Hayabuchi Y, Egawa Y, Takahama Y, Kitagawa T. Complete but not partial thymectomy in early infancy reduces T-cellmediated immune response: three-year tracing study after pediatric cardiac surgery. J Thorac Cardiovasc Surg 2013; 145: 656-662.e2.

23. Opiela SJ, Koru-Sengul T, Adkins B. Murine neonatal recent thymic emigrants are phenotypically and functionally distinct from adult recent thymic emigrants. Blood 2009; 113: 5635-5643.

24. Eysteinsdottir JH, Freysdottir J, Haraldsson A, Stefansdottir J, Skaftadottir I, Helgason $\mathrm{H}$, Ogmundsdottir $\mathrm{H}$. The influence of partial or total thymectomy during open heart surgery in infants on the immune function later in life. Clin Exp Immunol 2004; 136: 349-355.

25. Brearley S, Gentle TA, Baynham MI, Roberts KD, Abrams LD, Thompson RA. Immunodeficiency following neonatal thymectomy in man. Clin Exp Immunol 1987; 70: 322-327.

26. Wells WJ, Parkman R, Smogorzewska E, Barr M. Neonatal thymectomy: does it affect immune function? J Thorac Cardiovasc Surg 1998; 115: 1041-1046.

27. Mancebo E, Clemente J, Sanchez J, Ruiz-Contreras J, De Pablos P, Cortezon S, Romo E, Paz-Artal E, Allende LM. Longitudinal analysis of immune function in the first 3 years of life in thymectomized neonates during cardiac surgery. Clin Exp Immunol 2008; 154: 375-383.

28. Roosen J, Oosterlinck W, Meyns B. Routine thymectomy in congenital cardiac surgery changes adaptive immunity without clinical relevance. Interact Cardiovasc Thorac Surg 2015; 20: 101-106.

29. Madhok AB, Chandrasekran A, Parnell V, Gandhi M, Chowdhury D, Pahwa S. Levels of recent thymic emigrant cells decrease in children undergoing partial thymectomy during cardiac surgery. Clin Diagn Lab Immunol 2005; 12: 563-565.

30. Cao Q, Yin M, Zhou Y, Liu J, Sun K, Li B. Effect of thymectomy on cellular immune function. Front Biosci 2011; 16: 3036-3042.

31. van den Brink MRM, Alpdogan O, Boyd RL. Strategies to enhance T-cell reconstitution in immunocompromised patients. Nat Rev Immunol 2004; 4: 856-867.

32. Chaudhry MS, Velardi E, Dudakov JA, van den Brink MRM. Thymus: the next (re)generation. Immunol Rev 2016; 271: 56-71.

33. Zdrojewicz Z, Pachura E, Pachura P. The thymus: a forgotten, but very important organ. Adv Clin Exp Med 2016; 25: 369-375. 